\title{
Broad-Spectrum Resistance to Different Geographic Strains of Papaya ringspot virus in Coat Protein Gene Transgenic Papaya
}

\author{
Huey-Jiunn Bau, Ying-Huey Cheng, Tsong-Ann Yu, Jiu-Sherng Yang, and Shyi-Dong Yeh
}

First and fifth authors: Department of Plant Pathology, National Chung Hsing University, Taichung, Taiwan, Republic of China; second author: Department of Horticulture, Taiwan Agricultural Research Institute, Wufeng, Taiwan, Republic of China; and third and fourth authors: Department of Botany, National Chung Hsing University, Taichung, Taiwan, Republic of China. Accepted for publication 23 August 2002.

\begin{abstract}
Bau, H.-J., Cheng, Y.-H., Yu, T.-A., Yang, J.-S., and Yeh, S.-D. 2003. Broad-spectrum resistance to different geographic strains of Papaya ringspot virus in coat protein gene transgenic papaya. Phytopathology 93:112-120.

Papaya ringspot virus (PRSV) is a major limiting factor for cultivation of papaya (Carica papaya) in tropical and subtropical areas throughout the world. Although the coat protein (CP) gene of PRSV has been transferred into papaya by particle bombardment and transgenic lines with high resistance to Hawaii strains have been obtained, they are susceptible to PRSV isolates outside of Hawaii. This strain-specific resistance limits the application of the transgenic lines in other areas of the world. In this investigation, the CP gene of a local strain isolated from Taiwan, designated PRSV YK, was transferred into papaya via Agrobacterium-mediated transformation. A total of 45 putative transgenic lines were obtained and the presence of the transgene in papaya was confirmed by polymerase chain reaction amplification. When the plants

of transgenic lines were challenged with PRSV YK by mechanical inoculation, they showed different levels of resistance ranging from delay of symptom development to complete immunity. Molecular analysis of nine selected lines that exhibited different levels of resistance revealed that the expression level of the transgene is negatively correlated with the degree of resistance, suggesting that the resistance is manifested by a RNA-mediated mechanism. The segregation analysis showed that the transgene in the immune line 18-0-9 has an inheritance of two dominant loci and the other four highly resistant lines have a single dominant locus. Seven selected lines were tested further for resistance to three PRSV heterologous strains that originated in Hawaii, Thailand, and Mexico. Six of the seven lines showed varying degrees of resistance to the heterologous strains, and one line, 19-0-1, was immune not only to the homologous YK strain but also to the three heterologous strains. Thus, these CP-transgenic papaya lines with broad-spectrum resistance have great potential for use in Taiwan and other geographic areas to control PRSV.
\end{abstract}

Papaya (Carica papaya L.) is widely planted in tropical and subtropical areas. The fruit can be harvested 8 to 10 months after transplanting plants in the field, and fruit can be harvested continually year-round under normal conditions. A destructive disease caused by Papaya ringspot virus (PRSV) (30) is a major obstacle to large-scale commercial production of papaya (48). PRSV is a member of the genus Potyvirus, the largest and economically most important plant virus genus, and naturally is transmitted by aphids in a nonpersistent manner. PRSV first was recorded in southern Taiwan in 1975, and it has destroyed most of the papaya production in commercial orchards since then $(44,48)$.

Genetic resistance to PRSV has not been found within $C$. papaya $(4,22)$. Although tolerant selections of papaya were described, they were not commercially desirable $(3,4)$. Two mild strains of PRSV, HA 5-1 and HA 6-1 (47), derived from nitrousacid induction of a Hawaii severe strain HA (11), provided a high degree of cross protection in papaya against infection of PRSV HA under greenhouse and field conditions $(45,47)$. The use of cross protection as a control measure has become a routine practice in Taiwan since 1985 (45,50). However, under greenhouse conditions, high degrees of protection (90 to 100\%) against HA were observed (47), but relatively lower protection rates (50 to $60 \%$ ) were obtained when these mild strains were used to protect papaya against the severe strains from Taiwan (45). This strainspecific protection restricts the usefulness of the mild strains in Taiwan and other areas of the world outside of Hawaii (48).

Corresponding author: S.-D. Yeh; E-mail address: sdyeh@nchu.edu.tw

Publication no. P-2002-1114-01R

(C) 2003 The American Phytopathological Society
The concept of parasite-derived resistance (PDR) proposed by Sanford and Johnson (34) suggests that expressing genetic materials of a pathogen in a host would disrupt the essential pathogenic processes and hence result in resistance to the pathogen. Powell Abel et al. (29) demonstrated that transgenic tobacco plants expressing the coat protein (CP) gene of Tobacco mosaic virus (TMV) conferred resistance to TMV infection. Using this approach, the CP gene of the mild strain, PRSV HA 5-1, was engineered and transferred to tobacco plants, which showed delay and attenuation in symptom development when challenged with other unrelated potyviruses (19). Fitch et al. (8) successfully incorporated the CP gene of HA5-1 into papaya via microprojectile bombardment and obtained plants that were resistant to infection by the severe Hawaii HA strain (9). Among their transgenic papaya lines, line 55-1 was virtually immune to infection by HA (9). In addition, when the $R_{1}$ plants of line 55-1 were tested against 12 isolates of PRSV from different areas of the world, they were essentially effective against only the local Hawaii strain (39). As observed for classical cross protection, the strain-specific resistance of transgenic line 55-1 suggests that it shows promise for control of PRSV in Hawaii, but may not be effective in many regions outside of Hawaii.

Recently, we have developed an efficient method for generating transgenic papaya carrying the $\mathrm{CP}$ gene of a severe PRSV strain from Taiwan, by liquid-phase wounding of embryogenic tissues with Carborundum (1) followed with Agrobacterium-mediated transformation. This method was used in this investigation to obtain a total of 45 transgenic lines that were characterized and evaluated under greenhouse conditions. Different levels of broadspectrum resistance to the homologous Taiwan strain and heterologous strains from Hawaii, Thailand and Mexico, ranging from 
delay of symptom development to complete immunity, were observed. The transgenic papaya lines with the most prominent broad-spectrum resistance have a great potential to be applied in Taiwan and other geographic areas for control of PRSV.

\section{MATERIALS AND METHODS}

Transgenic papaya lines. The CP gene of PRSV YK, a severe mosaic strain originated from Taiwan (42), with a $\beta$-glucuronidase (GUS) leader transcribed from behind a CaMV 35S promoter and containing a nopaline synthase (NOS) terminator, was constructed in a Ti-vector with the nptII selection marker (1). The construct was transferred to Agrobacterium tumefaciens LBA4404 by the triparental mating method (28). Transformation of embryogenic tissues derived from immature zygotic embryos of papaya $(C$. papaya L. var. Tainung No. 2) was conducted by liquid-phase wounding with Carborundum as described (1). After somatic embryos derived from the selected transformed cells were germinated on the germination medium (46) for 2 to 4 weeks, the shoots were cultured in the shooting medium, Murashige-Skoog (MS) medium (25), supplemented with benzyladenine (BA) at $0.2 \mu \mathrm{g} / \mathrm{ml}, \alpha$-naphthalene acetic acid (NAA) at $0.02 \mu \mathrm{g} / \mathrm{ml}$, and kanamycin at $100 \mu \mathrm{g} / \mathrm{ml}$, for micropropagation (46). Multiple shoots derived from somatic embryos were excised and roots obtained as described (1). The putative transformed plants derived from a single somatic embryo were established in soil under temperature-controlled $\left(23\right.$ to $\left.28^{\circ} \mathrm{C}\right)$ greenhouse conditions and considered as an individual $\mathrm{R}_{0}$ line.

Polymerase chain reaction. Total DNA was extracted from leaves of putative transgenic or nontransformed papaya seedlings by the DNeasy Plant Mini kit (Qiagen Inc., Valencia, CA) and $1 \mu \mathrm{g}$ of RNase A-treated DNA was used as template for analysis by a polymerase chain reaction (PCR) (32). The forward primer MO926 (5'-TCTAAAAATGAAGCTGTGGA-3') and the reverse primer MO1008 (5'-GTGCATGTCTCTGTTGACAT-3'), reflecting nucleotide positions 9,257 to 9,276 and 10,096 to 10,077 of the PRSV YK CP sequence $(41,42)$, respectively, were used for amplification. The PCR was performed with periods of $1 \mathrm{~min}$ at $94^{\circ} \mathrm{C}, 2 \mathrm{~min}$ at $55^{\circ} \mathrm{C}$, and $3 \mathrm{~min}$ at $72^{\circ} \mathrm{C}$ for 30 cycles. PCR products were analyzed by electrophoresis in $1 \%$ agarose gel.

Inoculation of transgenic lines with the homologous strain of PRSV. Micropropagated $\mathrm{R}_{0}$ plants of transgenic papaya lines were grown in greenhouse for 1 month (to 6 to $8 \mathrm{~cm}$ in height) before inoculation. The plants were dusted with 600-mesh Carborundum on the third and the fourth youngest leaves and gently rubbed with $200 \mu \mathrm{l}$ of inoculum that was prepared by extraction of papaya leaf tissue 3 weeks after inoculation with PRSV YK in a $1: 10(\mathrm{wt} / \mathrm{vol})$ dilution in $0.01 \mathrm{M}$ potassium phosphate buffer $(\mathrm{pH}$ 7.0). Nontransformed papaya plants were used as a control. The inoculated plants were kept in a temperature-controlled greenhouse ( 23 to $28^{\circ} \mathrm{C}$ ) and symptom development was monitored daily for 7 weeks. Symptomless plants were checked for the presence of virus by double-antibody sandwich enzyme-linked immunosorbent assay (DAS-ELISA) (2) using the antiserum to PRSV (46). For this purpose, the $\gamma$-globulin of the antiserum to PRSV was purified by ion exchange column chromatography and conjugated with alkaline phosphatase (Jackson, West Grove, PA) (11). The substrate $p$-nitrophenyl phosphate was used for color development. Absorbance readings $(405 \mathrm{~nm})$ were taken by a Biotek EL 309 automated microplate reader (Bio-Tek Instruments, Inc., Winooski, VT).

Western blot analysis. Western blot analysis was conducted using the antiserum to PRSV (49) and goat anti-rabbit immunoglobulin $\mathrm{G}$ conjugated with alkaline phosphatase. Young leaves from papaya plants were homogenized in 6 volumes $(\mathrm{wt} / \mathrm{vol})$ of denaturation buffer $(50 \mathrm{mM}$ Tris- $\mathrm{HCl}, \mathrm{pH}$ 6.8, 4\% sodium dodecyl sulfate [SDS], 2\% 2-mercaptoethanol, $10 \%$ glycerol, $0.001 \%$ bromophenol blue). The extracts were heated at $100^{\circ} \mathrm{C}$ for $5 \mathrm{~min}$ and centrifuged at $8,000 \times g$ for 3 min to pellet plant debris. Total protein of each sample $(15 \mu \mathrm{l})$ was loaded on $10 \%$ polyacrylamide gel, separated by SDS-polyacrylamide gel electrophoresis (18), and subsequently transferred onto nitrocellulose membrane (BioRAD Laboratories, Hercules, CA.) (1). The immunostaining procedures were performed as described by the user's manual of GUS Gene Fusion System (Clontech Inc., Palo Alto, CA).

Northern blot analysis. Total RNA was isolated from young leaves of transgenic and nontransformed papaya seedlings by the ULTRASPEC RNA isolation system (Biotecx Laboratories, Houston, TX). Fifteen micrograms of total RNA was separated in a $1.2 \%$ agarose gel with formaldehyde and transferred onto Gene Screen Plus nylon membranes (DuPont Co., Boston, MA). Hybridization was performed using the ${ }^{32} \mathrm{P}$-labeled probe prepared from the PCR-amplified PRSV YK CP fragment (43) by the Primer-It II random primer labeling kit (Stratagene, LaJolla, CA).

Inoculation of transgenic lines with the heterologous strains of PRSV. Three heterogeneous strains of PRSV were used for evaluation of the resistance of seven selected transgenic lines, including HA (11), TH, and MX strains (provided by D. Gonsalves, Cornell University), that originated from Hawaii, Thailand, and Mexico, respectively. All strains were propagated in papaya cv. Tainung No. 2 and collected 21 days after inoculation for the preparation of challenge inoculums $(1: 10[\mathrm{wt} / \mathrm{vol}]$ in $0.01 \mathrm{M}$ potassium phosphate buffer, $\mathrm{pH}$ 7.0). Disease resistance was assessed by comparing the severity of symptoms on transgenic and nontransformed plants. Symptomless plants were checked for the presence of virus by DAS-ELISA as described above.

Segregation analysis of the transgenes. $R_{1}$ progeny of putative transgenic lines were obtained by crossing $\mathrm{R}_{0}$ lines with the nontransformed cv. Sunrise. The inheritance of the transgenes in the $R_{1}$ progeny was analyzed by petiole culturing on the medium containing kanamycin and by mechanical inoculation with PRSV YK. Resistance to kanamycin of $R_{1}$ progeny was performed by culturing petiole fragments (approximately $2 \mathrm{~mm}$ in length) excised from individual seedlings, after surface sterilization with $1 \%$ sodium hypochlorite, on the MS medium containing BA at $0.1 \mu \mathrm{g} / \mathrm{ml}, 2,4$-dichlorophenoxyacetic acid $(2,4-\mathrm{D})$ at $0.5 \mu \mathrm{g} / \mathrm{ml}$,

TABLE 1. Evaluation of Papaya ringspot virus (PRSV) strain YK coat protein transgenic papaya lines by mechanical inoculation with PRSV YK under greenhouse conditions

\begin{tabular}{|c|c|c|c|c|c|c|c|}
\hline \multirow{2}{*}{$\begin{array}{l}\text { Number of } \\
\text { transgenic lines }\end{array}$} & \multirow[b]{2}{*}{ Reaction type } & \multicolumn{6}{|c|}{ Percent plants showing symptoms after mechanical inoculation at day ${ }^{\mathrm{a}}$} \\
\hline & & 10 & 14 & 21 & 28 & 35 & 49 \\
\hline 16 & Susceptible & 100 & 100 & 100 & 100 & 100 & 100 \\
\hline 17 & Resistant & 0 & 0 & $40-50$ & $50-60$ & 60 & 60 \\
\hline 2 & Immune & 0 & 0 & 0 & 0 & 0 & 0 \\
\hline Untransformed control & $\ldots$ & 100 & 100 & 100 & 100 & 100 & 100 \\
\hline
\end{tabular}

${ }^{a}$ At least 10 plants of each line were tested for PRSV YK infection. Susceptible lines showed symptoms of mosaic and distortion on leaves, and water-soaked streaks on petioles and stems, similar to symptoms of the untransformed control. Resistant lines eventually showed the same symptoms as the susceptible lines, but had a 3- to 4-week delay in symptom development compared with the susceptible lines. Highly resistant lines showed symptoms of mild mottling or local spots on leaves. Immune lines showed no symptoms. 
and kanamycin at $100 \mu \mathrm{g} / \mathrm{ml}$. Formation of calli on the medium was recorded 2 weeks after culturing. To evaluate resistance, seedlings of progeny with or without the transgene were mechanically inoculated at the six- to eight-leaf stage, with PRSV YK prepared as described above. Plants on which symptoms developed within 14 days after inoculation were considered as having no resistance.

Cloning and sequencing the $3^{\prime}$-terminal regions of PRSV TH and MX RNAs. Total RNA was isolated from papaya leaves individually infected with PRSV TH or PRSV MX 3 weeks after mechanical inoculation. Oligo-d $\mathrm{T}_{(18)}$ primer was used to synthesize the first strand of cDNA from the $3^{\prime}$ end of the viral RNA by reverse transcription (RT) (33). The forward primer YK905 5'GCAGGGCCCCATATGTGTCT-3', reflecting the nucleotide positions 9,054 to 9,073 of the PRSV YK sequence (42) and with an ApaI site at the $5^{\prime}$ end, and the reverse primer oligo-d $\mathrm{T}_{(18)}-\mathrm{Nt}$, with an NotI site at the $5^{\prime}$ end, were used to amplify the CP gene of each virus by PCR performed as described above.

RT-PCR products of TH and MX were ligated with pCR-TOPO vector and cloned by One Shot transformation reaction using Escherichia coli $\mathrm{TOP} 10 \mathrm{~F}^{\prime}$ as competent cells (Invitrogen, San Diego, CA). DNA sequencing was manually determined by the dideoxynucleotide chain termination method (35) and confirmed by an automatic DNA sequencing system (ABI 377-19; PerkinElmer Applied Biosystems, Foster City, CA). Nucleotide sequences of the $\mathrm{CP}$ genes and the $3^{\prime}$ noncoding regions of $\mathrm{TH}$ and MX were assembled and compared with those of the published sequences of YK (41) and HA (51) by the PC/GENE 6.85 software (IntelliGenetics, Inc., Mountain View, CA). Multiple sequences alignment was performed by the PILEUP program of the GCG package (version 9.0; Genetics Computer Group, Madison, WI).

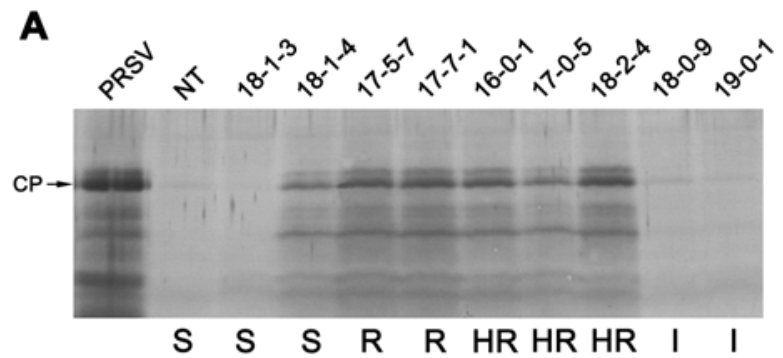

B

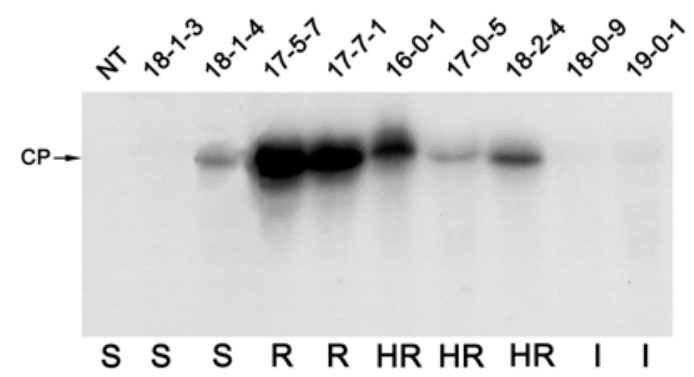

Fig. 1. Analyses of A, transgene expression by western blotting using the antiserum to Papaya ringspot virus (PRSV) coat protein $(\mathrm{CP})$ and of $\mathbf{B}$, accumulation of transgene transcripts by northern blotting using cDNA probes to the PRSV CP gene for the selected nine transgenic lines (18-1-3, 18-1-4, 17-5-7, 17-7-1, 16-0-1, 17-0-5, 18-2-4, 18-0-9, and 19-0-1). A, PRSV = PRSV-infected papaya used as a positive control, NT = nontransformed papaya. The arrow indicates the position of the 32-kDa PRSV CP. B, NT = nontransformed papaya. The arrow indicates the migration of a PRSV $\mathrm{CP}$ transcript of 1,100 nt; S, R, HR, and I denote susceptible, resistant, highly resistant, and immune lines as determined by mechanical inoculation, respectively. The similar amount of RNA loading in the gel was checked by ethidium bromide staining (data not shown).

\section{RESULTS}

Establishment of transgenic lines. After germination, putative transformed somatic embryos grew rapidly and formed multiple shoots on the shooting medium containing kanamycin at $100 \mu \mathrm{g} / \mathrm{ml}$. Nontransformed embryos were not able to germinate and gradually degenerated on this medium. Few pieces of embryogenic tissue turned green but mingled with white pale domains, apparently resulting from chimeric tissue that consisted of transformed and nontransformed cells. These tissues required an additional 2 to 4 weeks to develop somatic embryos. Shoots derived from an individual somatic embryo were regarded as an individual transgenic line. Multiple shoots of 1.0 to $1.5 \mathrm{~cm}$ were transferred to rooting media. A total of 63 papaya lines were established from the putative transgenic embryos. Among them, the presence of the $\mathrm{CP}$ transgene was confirmed in 45 lines by PCR which yielded an amplified product of $0.84 \mathrm{kbp}$ (data not shown). These lines were micropropagated by tissue culture and grown in a greenhouse for further evaluation.

Evaluation of the transgenic lines under greenhouse conditions. At least 10 plants for each of the 45 transgenic lines were inoculated with PRSV YK. Symptom development of transgenic lines was compared with that of nontransformed control plants. Nontransformed papaya seedlings infected with PRSV YK showed vein clearing on the newly emerged leaves at 10 to 14 days after inoculation and subsequently displayed mosaic and distortion on leaves and water-soaked streaks on petioles and stems (data not shown).

During the test period of 7 weeks, the transgenic plants exhibited varying levels of resistance, as shown by the percentages of inoculated plants that displayed visible symptoms. Based on this, the transgenic plants were classified into four categories, including susceptible, resistant, highly resistant, and immune types (Table 1). Sixteen lines of transgenic papaya were classified as the susceptible type because was no delay in development of severe symptoms as compared with the nontransformed controls. Seventeen lines were considered as the resistant type, with a 3- to 4-week delay in development of symptoms and up to $60 \%$ of test plants infected 7 weeks after inoculation. Ten lines were classified as the highly resistant type, with a 4- to 5-week delay in development of attenuated symptoms and only 20 to $30 \%$ of test plants infected 7 weeks after inoculation. Two lines, 18-0-9 and 19-0-1, were regarded as the immune type because they did not show any symptoms during a test period of 4 months. All plants of these two lines were negative in ELISA tests 7 weeks after inoculation, indicating that virus replication was completely suppressed.

The infected plants of resistant and highly resistant lines did not show the vein-clearing symptom on the newly emerged leaves as shown in controls. In plants of resistant lines, chlorotic spots on the newly developed leaves indicated the onset of symptoms, which gradually led to mottling or mosaic when leaves expanded thereafter. In plants of highly resistant lines, chlorotic spots were first observed on the newly expanded leaves, but gradually became localized to small sectors later. However, the new leaves of most plants of the resistant and highly resistant lines with attenuated symptoms became symptomless 2 to 3 months after inoculation and the virus accumulation in the recovered leaves could not be detected by ELISA.

Correlation of resistant phenotypes to the expression level of the transgene. Plants of nine lines from the four different types described above were selected to analyze the expression levels of the $\mathrm{CP}$ transgene by Western and Northern analyses. A 32-kDa protein reacted with the antiserum to PRSV CP was detected in plants of lines 18-1-4, 17-5-7, 17-7-1, 16-0-1, 17-0-5, 18-2-4, and PRSV-infected control plants; but not in lines 18-1-3, 18-0-9, 19$0-1$, and the nontransformed healthy control (Fig. 1A). Accumulations of the $\mathrm{CP}$ transcript in cytoplasm often correlated with protein expression levels as determined by Northern blot analysis 
(Fig. 1B). Two moderate resistant lines, 17-5-7 and 17-7-1, accumulated higher levels of transgene transcript than those of two highly resistant lines $16-0-1$ and $17-0-5$. On the other hand, both the transcript and the protein of the transgene were not detected in the susceptible line 18-1-3 and the immune lines 18-09 and 19-0-1. Except for the susceptible lines 18-1-3 and 18-1-4, the resistance levels of the other seven selected lines were generally inversely correlated to the levels of steady state RNA and protein accumulation of the transgene.

Segregation of the transgene in $R_{1}$ progeny. Four highly resistant lines, 16-0-1, 17-0-1, 17-0-5 and 18-2-4, and one immune line, 18-0-9, were crossed with the nontransformed cv. Sunrise and seed were collected for the analysis of inheritance of the transgene. The analysis was performed by determining the expression of the nptII gene, and also by mechanical inoculation with PRSV YK strain to analyze for the segregation of the CP gene. When petiole segments of $\mathrm{R}_{1}$ progenies were cultured for 2 weeks in the presence of kanamycin, calli vigorously developed from the segments that possessed the nptII gene while those without the nptII gene developed browning and declining petioles. Segregation ratios of the $n p t I I$ gene of $\mathrm{R}_{1}$ progenies of four highly resistant transgenic lines were 1:1 (Table 2), indicating that it was integrated into the chromosome at one single locus. A segregation ratio of 3:1 was found for the immune line 18-0-9 (Table 2), indicating that the $n p t \mathrm{II}$ transgene was inserted at two loci.

In mechanical inoculation tests, all of the nontransformed plants exhibited the vein-clearing symptom within 14 days after inoculation. Therefore, $\mathrm{R}_{1}$ progeny showing this symptom within 14 days after inoculation were considered to contain no $\mathrm{CP}$ transgene. The results showed that the $\mathrm{CP}$ transgene was inserted at a single locus in lines 16-0-1, 17-0-1, 17-0-5, and 18-2-4, but at two loci in line 18-0-9 (Table 3). The statistical analysis of the inoculation results matched those obtained with the kanamycin resistance test. Moreover, all individual plants of $\mathrm{R}_{1}$ progenies whose petiole segments degenerated on the kanamycin selection medium provided no resistance to virus infection.

Response of transgenic papaya lines to various PRSV strains. $\mathrm{R}_{0}$ plants of two resistant lines (17-5-7 and 17-7-1), three highly resistant lines (16-0-1, 17-0-5, and 18-2-4), and two immune lines (18-0-9 and 19-0-1), as determined by inoculation with PRSV YK, were further selected to evaluate their resistance to three PRSV strains from other geographical regions, including Hawaii, Thailand, and Mexico (Table 4). Plants of the lines 17-5-7 and $17-7-1$ were 50 to $100 \%$ infected with these three PRSV strains 7 weeks postinoculation. Although it was observed that symptom development in most of the inoculated plants of these transgenic lines was delayed by 10 to 14 days, the symptoms were as severe as those of nontransformed plants 7 weeks postinoculation. Plants of the three highly resistant lines 16-0-1, 17-0-5, and 18-2-4 offered a higher degree of resistance to these three PRSV strains than those induced on nontransformed plants: 35 to $75 \%$ infected, and the symptoms were milder, chlorotic spots or mottling on the expanded leaves,. The plants of immune line 18-09 were completely resistant to HA, but with 20 and $30 \%$ infection by the TH and MX strains, respectively. However, plants of line 19-0-1 were immune not only to PRSV YK strain but also to the HA, TH, and MX strains (Fig. 2A to D). Inoculated plants of this line did not show any symptoms and all tested negative with ELISA 7 weeks after inoculation.

As a comparison, we also challenged two high $\mathrm{CP}$ expressor lines (17-5-7 and 17-7-1) and two immune lines (18-0-9 and 19-0-1) with Papaya leaf-distortion mosaic virus (PLDMV), a potyvirus isolated from Taiwan that can cause systemically severe infection on papaya (17), in order to test whether these lines possessed a form of broad-spectrum resistance against infection by a heterologous potyvirus. The results showed that there were no apparent resistance and no delay in symptom development observed in these four lines (data not shown).

Comparison of the sequences of the $3^{\prime}$ terminal region of PRSV YK with those of three different geographic strains. The results of the nucleotide comparison of the $3^{\prime}$ terminal regions of TH and MX with those of the published strains of YK (43) and HA (51) are shown in Table 5. The sequence of the CP gene of YK shared nucleotide identities of $90.9,89.7$, and $92.5 \%$ with those of $\mathrm{HA}, \mathrm{MX}$, and $\mathrm{TH}$, respectively, and the $3^{\prime}$ noncoding region shared $92.3,93.7$, and $95.3 \%$, respectively. The results indicated that the $3^{\prime}$ noncoding region is more conserved than the $\mathrm{CP}$ gene among the four strains. When YK was compared with HA5-1 (a mild strain induced from HA) $(42,47)$, the CP gene and $3^{\prime}$ noncoding region showed 90.9 and $92.3 \%$ nucleotide identities, respectively.

TABLE 2. Segregation ratios of the $\mathrm{R}_{1}$ progenies of the Papaya ringspot virus strain YK coat protein transgenic papaya lines as determined by petiole culturing on the kanamycin $(100 \mu \mathrm{g} / \mathrm{ml})$ selection medium for 2 weeks

\begin{tabular}{|c|c|c|c|c|c|c|}
\hline \multirow[b]{2}{*}{ Transgenic lines } & \multicolumn{2}{|c|}{ Number of seedlings ${ }^{\mathrm{a}}$} & \multirow[b]{2}{*}{ Segregation ratio } & \multirow[b]{2}{*}{ Predicted $n p t I I$ locus } & \multirow[b]{2}{*}{$\chi^{2}$} & \multirow[b]{2}{*}{$P^{\mathrm{b}}$} \\
\hline & Resistant & Sensitive & & & & \\
\hline $16-0-1$ & 48 & 32 & $1: 1$ & 1 & 2.800 & $0.05-0.10$ \\
\hline $17-0-1$ & 55 & 45 & $1: 1$ & 1 & 0.810 & $0.30-0.40$ \\
\hline $18-0-9$ & 141 & 59 & $3: 1$ & 2 & 2.160 & $0.10-0.20$ \\
\hline $18-2-4$ & 87 & 109 & $1: 1$ & 1 & 2.469 & $0.10-0.20$ \\
\hline Tainung No. 2 & 0 & 50 & $\ldots$ & $\ldots$ & $\ldots$ & $\ldots$ \\
\hline
\end{tabular}

a Resistant or sensitive to kanamycin.

b Probability of goodness of fit was set at a significant level of 0.05 .

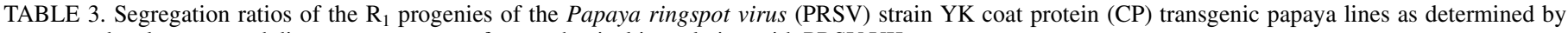
symptom development and disease percentages after mechanical inoculation with PRSV YK

\begin{tabular}{|c|c|c|c|c|c|c|}
\hline \multirow[b]{2}{*}{ Plant lines ${ }^{\mathrm{a}}$} & \multicolumn{2}{|c|}{ Symptoms found on no. of plants 14 day postinoculation } & \multirow[b]{2}{*}{ Segregation ratio } & \multirow[b]{2}{*}{ Predicted CP locus } & \multirow[b]{2}{*}{$\chi^{2}$} & \multirow[b]{2}{*}{$P^{b}$} \\
\hline & Vein-clearing and mosaic & Symptomless & & & & \\
\hline $16-0-1$ & 92 & 114 & $1: 1$ & 1 & 2.14 & $0.10-0.20$ \\
\hline $17-0-1$ & 174 & 187 & $1: 1$ & 1 & 0.40 & $0.50-0.60$ \\
\hline $17-0-5$ & 435 & 473 & $1: 1$ & 1 & 1.50 & $0.20-0.30$ \\
\hline $18-0-9$ & 94 & 272 & $3: 1$ & 2 & 0.09 & $0.70-0.80$ \\
\hline $18-2-4$ & 103 & 93 & $1: 1$ & 1 & 2.84 & $0.05-0.10$ \\
\hline Tainung No. 2 & 35 & 0 & $\ldots$ & $\ldots$ & $\ldots$ & $\ldots$ \\
\hline
\end{tabular}

a $\mathrm{R}_{1}$ plant lines crossed with cv. Sunrise.

${ }^{\mathrm{b}}$ Probability of goodness of fit was set at a significant level of 0.05 . 
The alignment of the nucleotide sequences of the CP genes and the $3^{\prime}$ noncoding regions of the strains HA, MX, TH, and YK are shown in Figure 3. For the $\mathrm{CP}$ genes, it was noticed that the central and the $\mathrm{C}$-terminal regions are more conserved, whereas the $\mathrm{N}$-terminal region is more variable. Also, the result indicates that the 3'-terminal 100 nucleotides of the four strains are highly conserved, sharing nucleotide identities of 97 to $98 \%$ (Fig. 3).

\section{DISCUSSION}

A total of 45 transgenic papaya lines carrying the PRSV YK CP gene were propagated by micropropagation and classified into four different types based on their responses to mechanical inoculation with PRSV YK. In addition to the susceptible phenotypes, 17 lines were resistant, 10 lines were highly resistant, and 2 lines were immune to YK infection. These different phenotypic types of resistance to the homologous virus strains have been well documented in previous studies and are characteristics of virus derived-resistance phenomena $(12,15,37,38)$. However, in this investigation, two lines, 18-0-9 and 19-0-1, were found to be immune to PRSV YK and they also provided broad-spectrum resistance to various PRSV strains from different geographic areas (i.e., HA, TH, and MX strains). Our results indicate that the resistance of these two lines are less strain-specific and may provide more substantial control of PRSV in different geographic areas than the previous reported transgenic papaya lines carrying the $\mathrm{CP}$ of the Hawaiian strain (39). In those studies, $\mathrm{R}_{1}$ transgenic papaya plants of line 55-1 (9) were tested for resistance against 12 isolates of PRSV from different geographical areas of the world

TABLE 4. Responses of $\mathrm{R}_{0}$ plants of selected coat protein (CP)-transgenic papaya lines after mechanical inoculation with four strains of Papaya ringspot virus originating from different geographic areas

\begin{tabular}{|c|c|c|c|c|}
\hline \multirow[b]{2}{*}{ Line, days postinoculation ${ }^{\mathrm{a}}$} & \multicolumn{4}{|c|}{ Plants with symptoms $(\%)^{\mathrm{b}}$} \\
\hline & YK & HA & $\mathrm{TH}$ & MX \\
\hline \multicolumn{5}{|l|}{$17-5-7(\mathrm{CP}+)$} \\
\hline 14 & 0 & 40 & 50 & 50 \\
\hline 28 & 50 & 50 & 50 & 60 \\
\hline 42 & 50 & 50 & 60 & 60 \\
\hline \multicolumn{5}{|l|}{ 17-7-1 (CP+) } \\
\hline 14 & 0 & 0 & 0 & 0 \\
\hline 28 & 25 & 75 & 70 & 75 \\
\hline 42 & 65 & 100 & 100 & 100 \\
\hline \multicolumn{5}{|l|}{$16-0-1(\mathrm{CP}+)$} \\
\hline 14 & 0 & 5 & 30 & 15 \\
\hline 28 & 0 & 35 & 45 & 65 \\
\hline 42 & 20 & 35 & 45 & 65 \\
\hline \multicolumn{5}{|l|}{$17-0-5(\mathrm{CP}+)$} \\
\hline 14 & 0 & 5 & 15 & 5 \\
\hline 28 & 0 & 40 & 40 & 65 \\
\hline 42 & 20 & 75 & 50 & 65 \\
\hline \multicolumn{5}{|l|}{$18-2-4(\mathrm{CP}+)$} \\
\hline 14 & 0 & 0 & 0 & 0 \\
\hline 28 & 0 & 25 & 30 & 45 \\
\hline 42 & 0 & 45 & 35 & 50 \\
\hline \multicolumn{5}{|l|}{$18-0-9(\mathrm{CP}-)$} \\
\hline 14 & 0 & 0 & 0 & 0 \\
\hline 28 & 0 & 0 & 10 & 30 \\
\hline 42 & 0 & 0 & 20 & 30 \\
\hline \multicolumn{5}{|l|}{$19-0-1(\mathrm{CP}-)$} \\
\hline 14 & 0 & 0 & 0 & 0 \\
\hline 28 & 0 & 0 & 0 & 0 \\
\hline 42 & 0 & 0 & 0 & 0 \\
\hline \multicolumn{5}{|l|}{ Control } \\
\hline 14 & 100 & 100 & 100 & 100 \\
\hline 28 & 100 & 100 & 100 & 100 \\
\hline 42 & 100 & 100 & 100 & 100 \\
\hline
\end{tabular}

${ }^{\text {a }} \mathrm{CP}+=$ positive in western blotting and $\mathrm{CP}-=$ negative in western blotting .

b Numbers indicate the percentage of plants showing symptoms as determined from 20 plants of each line. Strains from YK = Taiwan, HA = Hawaii, $\mathrm{TH}=$ Thailand, and MX = Mexico. and the results showed an apparently strain-specific protection against infection by the local Hawaii strains. Although the $\mathrm{R}_{1}$ plants conferred variable levels of resistance to some isolates, the phenomenon of incomplete protection is similar to our selected CP expressor line 17-7-1 in that resistance was expressed only as delay of symptom development. A shorter delay in symptom development and no symptom attenuation for the Hawaii transgenic lines against Thailand, Ecuador, Okinawa (39), and Taiwan strains (10) indicated that these $R_{1}$ transgenic plants provided a promising way for controlling PRSV in Hawaii (20), but may not be effective in many regions outside Hawaii. Conversely, our other selected four lines of $\mathrm{CP}$ expressors (17-5-7, 16-0-1, 17-0-5, and 18-2-4) also provide high degrees of resistance to the heterologous HA, TH, and MX strains, although not as strong as that to the homologous Taiwan YK strain.

Two mechanisms are known that function to allow resistance to virus infection in transgenic plants expressing viral sequences; protein-mediated resistance and RNA-mediated resistance (21). A common characteristic of protein-mediated resistance is that resistance usually correlates with high levels of expression of the transgene; however, RNA-mediated resistance typically is associated with low or nondetectable transgene expression (21). RNAmediated resistance is triggered by the posttranscriptional gene silencing (PTGS), which is manifested by specific degradation of cytoplasmic transgene RNAs in transgenic plants $(7,13)$. The resistance is strong but has a narrow spectrum due to its sequence homology-dependent nature. RNA-mediated resistance often is associated with the presence of multiple copies of the transgene and the methylation of the transgene in the transcribed region $(6,12,15,24)$.

The two selected resistant lines (17-5-1 and 17-7-1) accumulated higher levels of RNA and CP than those in the other three selected highly resistant lines (16-0-1, 17-0-5, and 18-2-4). However, the CP expression in two immune lines (18-0-9 and 19-0-1) was undetectable. The inverse correlation between the resistance levels and the expression levels of the transgene has been noticed in many previous reports regarding RNA-mediated resistance or PTGS $(7,40)$. Moreover, line 18-1-4 is a CP expressor, but did not confer resistance to YK infection. Thus, our results of western and northern analyses suggested that these selected lines are resistant possibly due to an RNA-mediated rather than protein-mediated mechanism. Interestingly, the presence of the transgene in the susceptible line 18-1-3 was detected by PCR, but the transgene expression was not detected.

RNA-mediated resistance against viruses often is associated with the presence of multiple copies of the transgene (36). This also matched well with our observation that the segregation ratios indicated that the immune line 18-0-9 has a two-locus heredity of the $\mathrm{CP}$ transgenes. This line provided higher resistance than three other highly resistant lines (16-0-1, 17-0-5, and 18-2-4) that possess heredity of a single locus. However, when Southern blot was applied to check the real copy number of the $\mathrm{CP}$ transgene in the seven selected lines, only two lines (16-0-1 and 17-0-5) were confirmed with one-copy insertion in the chromosome (data not shown); the $\mathrm{CP}$ transgene in the others was detected as a signal located at the high molecular weight position or not detected. We speculate that this phenomenon might be due to (i) the methylation of the transcribed regions of the transgene yielding chromosomal DNAs that were not digestible by the restriction enzymes used or (ii) papaya latex that may affect the DNA quality when purified by general chromosome DNA isolation methods. The Southern analysis of these lines was not conclusive; therefore, the possibility of the $\mathrm{CP}$ transgene inserted as tandem repeats that collectively behave as a single locus cannot be excluded.

Meuller et al. (24) reported RNA-mediated resistance to be effective against viruses with sequence identity of $88 \%$ or greater. Guo et al. (14) demonstrated that the Plum pox virus (PPV) isolate PPV-PS has an $84 \%$ sequence identity with isolate PPV-R and can 
overcome PPV-R-transgenic plants. Jones et al. also showed that the $89 \%$ sequence identity of the NIb gene of Pea seed-borne mosaic virus is a borderline for the specificity required for triggering gene silencing (16). Moreno et al. suggested that, when designing transgenes for potyvirus resistance, it is important to select for regions of near $90 \%$ identity between strains to obtain a wider resistance (23). Our sequence data showed that both the $\mathrm{CP}$ coding region and the $3^{\prime}$ noncoding region have more than $89 \%$ nucleotide identities between $\mathrm{YK}$ and the other three isolates. However, in our seven selected lines, only 18-0-9 and 19-0-1 have complete resistance to all virus isolates. The others lines display different levels of strain-specific resistance. Recently, our results showed that the highly resistant lines 17-0-5 and 18-2-4 displayed a strong strain-specific resistance at the young developmental stage (5-cm height) but, when the plants reached an older stage (10-cm height) showed a high level of broad-spectrum resistance (data not shown). We speculated that the developmental factors of the plant or the environmental conditions may play a role in triggering the integrity of homology-dependent gene silencing.

Multiple explanations exist for the broad-spectrum resistance provided by our transgenic lines compared with the Hawaii transgenic lines. First, it should be considered that the pathogenicity of PRSV YK is much more severe than PRSV HA; the former caused severe mosaic, stunting, and induced wilting under highdose inoculation and the latter caused only leaf mosaic and distortion without wilting. Thus, our transgenic lines initially were selected under greater pressure than that for the Hawaii lines. Second, the number of our $\mathrm{R}_{0}$ lines (45 lines) for the evaluation of resistance to virus infection is much more than the 9 lines of Fitch et al. (9). Selection from a larger transgenic population should have a better chance to obtain lines with a broader spectrum of resistance. Third, the sequence comparison showed that the central and the $\mathrm{C}$-terminal regions of the $\mathrm{CP}$ open reading frames and the $3^{\prime}$ noncoding regions are highly conserved between YK and the other three isolates (Fig. 3). It is possible that the RNAmediated resistance is targeted to these regions to induce broadspectrum resistance. Previous studies also mentioned that the $3^{\prime}$ region of the transgene is often a target of the PTGS mechanism (6). When compared with Fitch's construct, it was found that only 49 nucleotides of the $3^{\prime}$ noncoding region of PRSV genome was included in the $3^{\prime}$ end of their transgene (19), much shorter than in our case (206 nt). This shorter 3' noncoding region may not be long enough to trigger the broad-spectrum gene silencing. We

TABLE 5. Nucleotide percentages of the coat protein gene (in upper corner) and the $3^{\prime}$ noncoding region (in lower corner) of Papaya ringspot virus YK isolate (a mosaic strain from Taiwan) compared with those of HA (a severe strain from Hawaii), HA 5-1 (a mild strain induced from HA), MX (a severe strain from Mexico), and TH isolates (a severe strain from Thailand) ${ }^{\mathrm{a}}$

\begin{tabular}{lccccc}
\hline Virus strains & YK & HA5-1 & HA & MX & TH \\
\hline YK & $\ldots$ & 90.9 & 90.9 & 89.7 & 92.5 \\
HA5-1 & 92.3 & $\ldots$ & 99.8 & 95.0 & 89.8 \\
HA & 92.3 & 100 & $\ldots$ & 95.1 & 90.0 \\
MX & 93.7 & 93.7 & 93.7 & $\ldots$ & 88.5 \\
TH & 95.3 & 90.7 & 90.7 & 91.1 & $\ldots$ \\
\hline
\end{tabular}

a Sources for the sequence of YK was from Wang et al. (43), HA was Wang and Yeh (38), and HA 5-1 from Quemada et al. (31). The sequences of MX and $\mathrm{TH}$ were determined in this investigation. Sequence comparison was conducted with PC/GENE software (version 6.85, IntelliGenetics, Inc., Mountain View, CA).
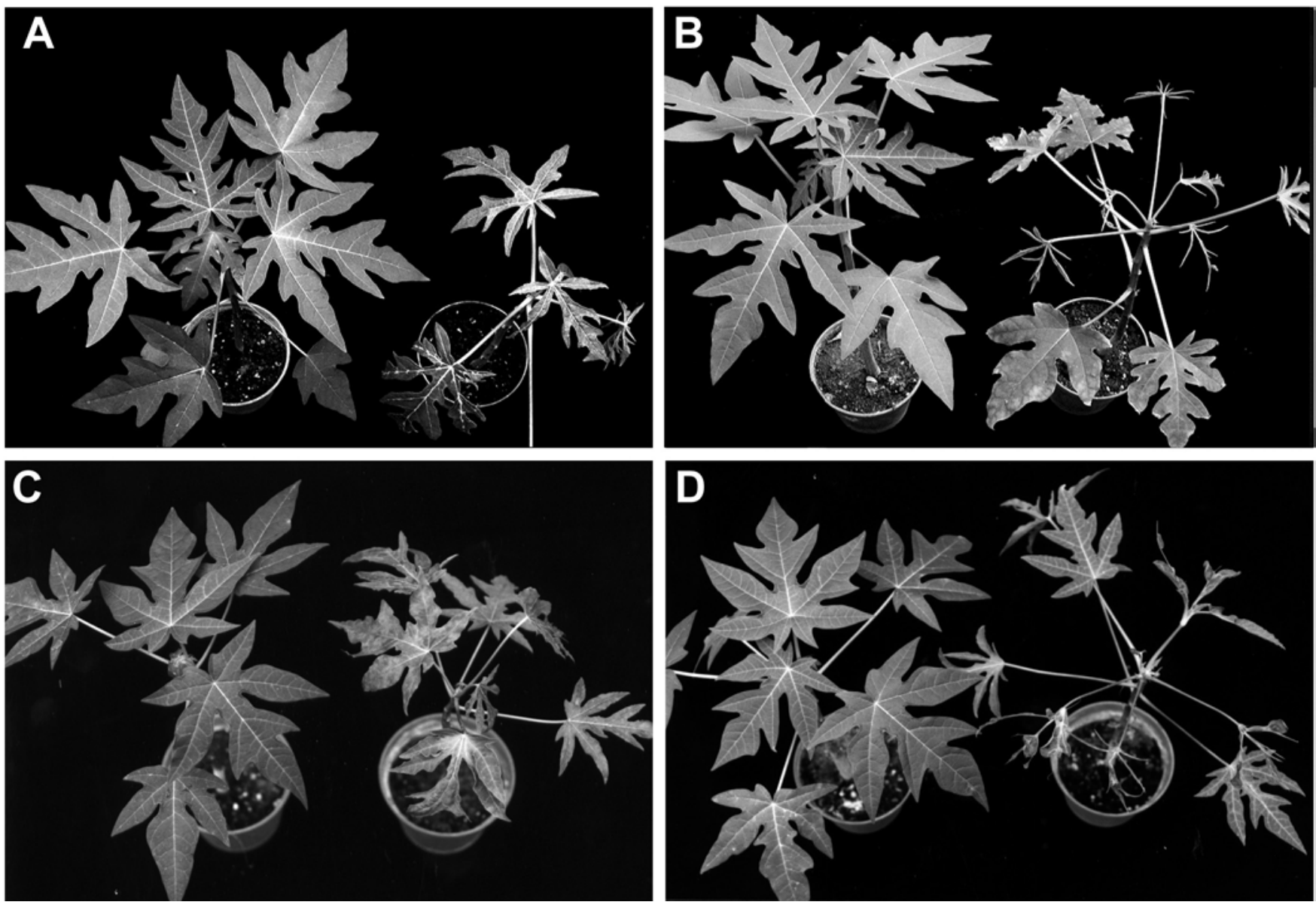

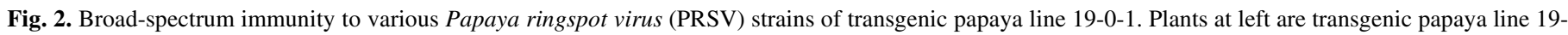

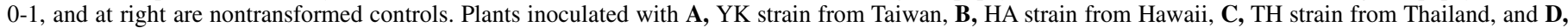
MX strain from Mexico. Photographs were taken 7 weeks postinoculation. 
believe that these highly conserved regions of the $\mathrm{CP}$ gene and $3^{\prime}$, or the highly conserved regions of other PRSV genes such as the RNA replicase domains of the NIb gene $(43,51)$, can be used to generate broad-spectrum resistance mediated by RNA silencing. Fourth, our lines 18-0-9 and 19-0-1 may trigger the RNA-mediated resistance more completely at earlier developmental stages than line 55-1, thus generating high degrees of resistance to all strains. PTGS has been shown to be developmentally regulated; the young seedlings expressed the transgene at a high level but, later in the development of the plant, the expression was silenced $(5,26,27)$. This phenomenon has been observed in our recent investigations in which three highly resistant lines, 16-0-1,17-0-5, and 18-2-4, displayed high levels of transgene expression at a 5-cm height stage of plant growth, while two immune lines, 18-0-9, 19-0-1, were silenced at the same stage (data not shown). Among the above possibilities, it seems that a transgene construct containing the complete coding region of the $\mathrm{CP}$ gene and the complete $3^{\prime}$ noncoding regions for a potyvirus coupled with screening from large numbers of transgenic lines provides a better chance to obtain transgenic lines which confer a broader spectrum of resistance against different strains.

Two immune lines, 18-0-9 and 19-0-1, provide a broad-spectrum resistance to homologous and heterologous strains of PRSV originating from Taiwan and different geographic regions; they

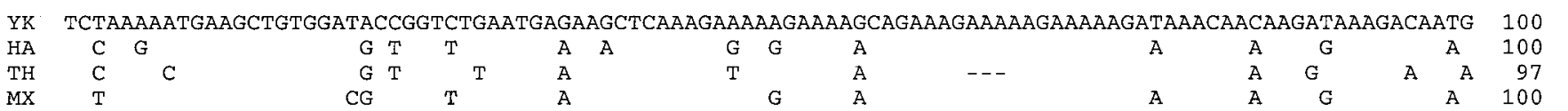

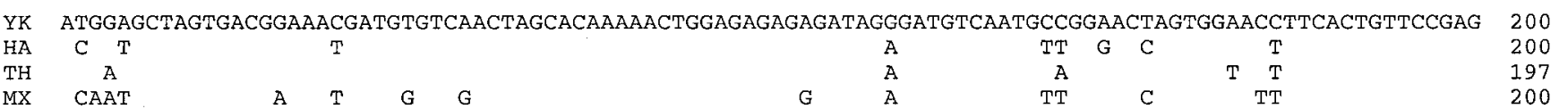

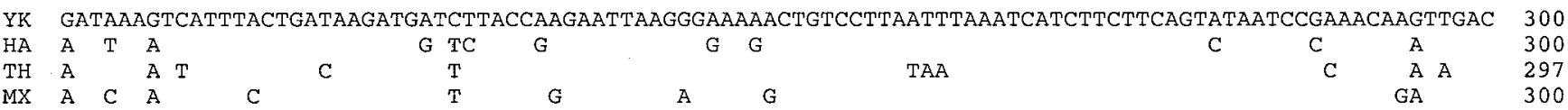

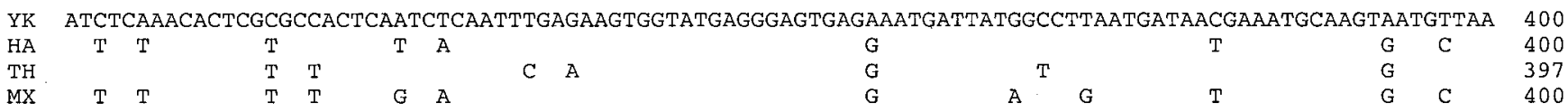

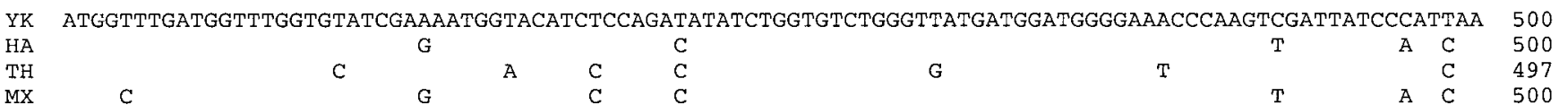

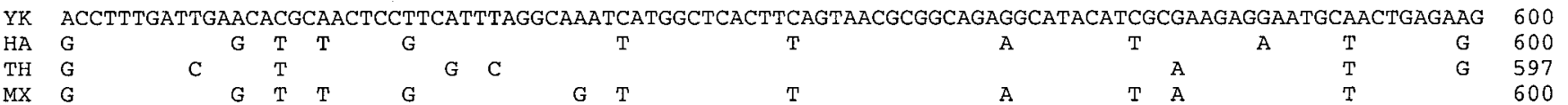

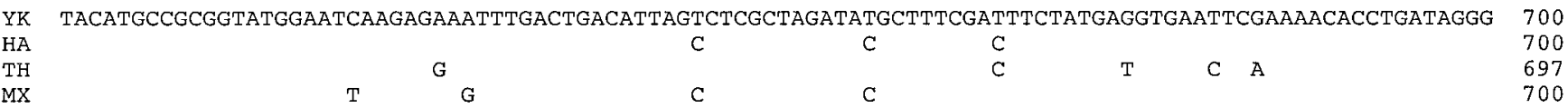

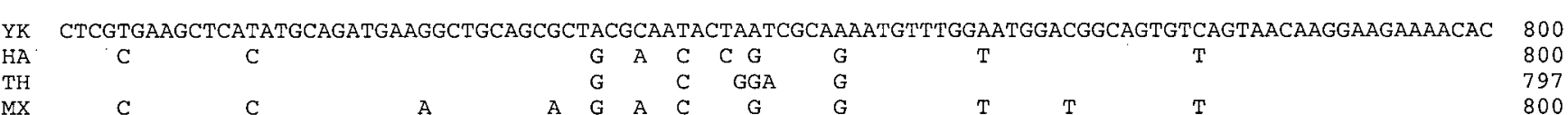

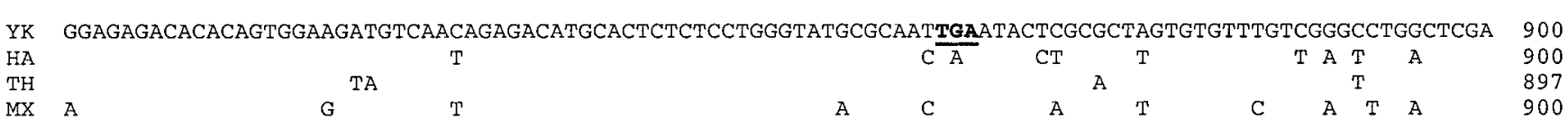

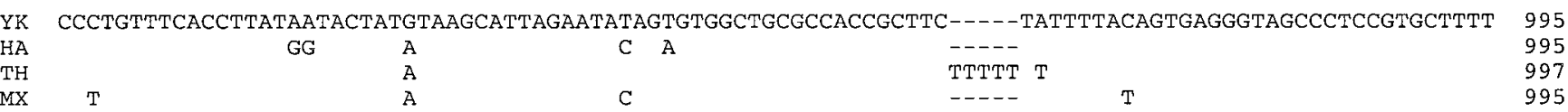

$\begin{array}{lrrr}\text { YK } & \text { AGTGTTATCGAGTTCTCTGAGTCTCCATACAGTGTGGGTGGCCCACGTGCTATTCGAGCCTCTTGGAATGAGAG } & 1070 \\ \text { HA } & \text { A } & \text { A } & \text { A } \\ \text { TH } & & & \text { A } \\ \text { MX } & \text { A } & \text { T } & \text { A }\end{array}$

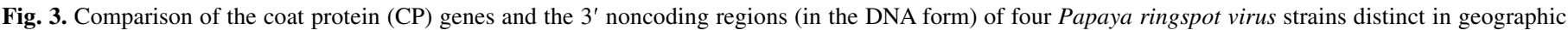

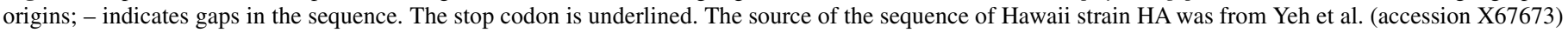

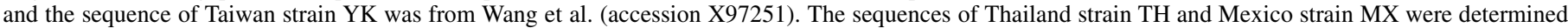
in this study. Sequence alignment was conducted by the PILEUP program of the GCG package (version 9.0, Genetics Computer Group, Madison, WI). 
show great potential to be applied in Taiwan and other geographic areas such as Hawaii, Thailand, and Mexico for the control of PRSV.

\section{ACKNOWLEDGMENTS}

This study was supported in part by the grants from the Council of Agriculture (88 Biotech-2.1-Food-02[1-1]) and from the National Science Council (NSC 87-2312-B005-005 and NSC 89-2312-B005-001) of Taiwan, Republic of China.

\section{LITERATURE CITED}

1. Cheng, Y. H., Yang, J. S., and Yeh, S. D. 1996. Efficient transformation of papaya by coat protein gene of papaya ringspot virus mediated by Agrobacterium following liquid-phase wounding of embryogenic tissues with carborundum. Plant Cell Rep. 16:127-132.

2. Clark, M. F., and Adams, A. N. 1977. Characteristics of the microplate method of enzyme-linked immunosorbent assay (ELISA) for the detection of plant viruses. J. Gen. Virol. 34:475-483.

3. Conover, R. A. 1976. A program for development of papaya tolerant to the distortion ringspot virus. Proc. Fla. State Hortic. Soc. 89:229-231.

4. Conover, R. A., and Litz, R. E. 1978. Progress in breeding papaya with tolerance to papaya ringspot virus. Proc. Fla. State Hortic. Soc. 91:182184.

5. Dehio, C., and Schell, J. 1994. Identification of plant genetic loci involved in a posttranscriptional mechanism for meiotically reversible transgene silencing. Proc. Natl. Acad. Sci. USA 91:5538-5542.

6. English, J. J., Mueller, E., and Baulcombe, D. C. 1996. Suppression of virus accumulation in transgenic plants exhibiting silencing of nuclear genes. Plant Cell 8:179-188.

7. Fagard, M., and Vaucheret, H. 2000. (Trans) Gene silencing in plants: How many mechanism? Annu. Rev. Plant Mol. Biol. 51:167-194.

8. Fitch, M. M. M., Manshardt, R. M., Gonsalves, D., Slightom, J. L., and Sanford, J. C. 1990. Stable transformation of papaya via microprojectile bombardment. Plant Cell Rep. 9:189-194.

9. Fitch, M. M. M., Manshardt, R. M., Gonsalves, D., Slightom, J. L., and Sanford, J. C. 1992. Virus resistant papaya plants derived from tissues bombarded with the coat protein gene of papaya ringspot virus. Bio/Technology 10:1466-1472.

10. Gonsalves, D. 1998. Control of papaya ringspot virus in papaya: A case study. Annu. Rev. Phytopathol. 36:415-437.

11. Gonsalves, D., and Ishii, M. 1980. Purification and serology of papaya ringspot virus. Phytopathology 70:1028-1032.

12. Goodwin, J., Chapman, K., Swaney, S., Parks, T. D., Wernsman, E. A., and Doughtery, W. G. 1996. Genetic and biochemical dissection of transgenic RNA-mediated virus resistance. Plant Cell 8:95-105.

13. Grant, S. R. 1999. Dissecting the mechanisms of posttranscriptional gene silencing: Divide and conquer. Cell 96:303-306.

14. Guo, H. S., Cervera, M. T., and Garcia, J. A. 1998. Plum pox potyvirus resistance associated to transgene silencing that can be stabilized after different number of plant generations. Gene 206:263-272.

15. Jacquet, C., Ravelonandro, M., Bachelier, J. C., and Dunez, J. 1998. High resistance to plum pox virus (PPV) in transgenic plants containing modified and truncated forms of PPV coat protein gene. Transgenic Res. 7:29-39.

16. Jones, A. L., Johansen, I. E., Bean, S. J., Bach, I., and Maule, A. J. 1998. Specificity of resistance to pea seed-borne mosaic potyvirus in transgenic peas expressing the viral replicase (NIb) gene. J. Gen. Virol. 79:3129-3137.

17. Kawano, S., and Yonaha, T. 1992. The occurrence of papaya leaf-distortion mosaic virus in Okinawa. Tech. Bull. FFTC (Food Fertil. Technol. Cent. Asian Pac. Reg. Taipei) 132:13-23.

18. Laemmli, U. K. 1970. Cleavage of structural proteins during the assembly of the head of bacteriophage T-4. Nature 227:680-685.

19. Ling, K., Namba, S., Gonsalves, C., Slightom, J. L., and Gonsalves, D. 1991. Protection against detrimental effects of potyvirus infection in transgenic tobacco plants expressing the papaya ringspot virus coat protein gene. Bio/Technology 9:752-758.

20. Lius, S., Manshardt, R. M., Fitch, M. M. M., Slightom, J. L., Sanford, J. C., and Gonsalves, D. 1997. Pathogen-derived resistance provides papaya with effective protection against papaya ringspot virus. Mol. Breed. 3:161-168.

21. Lomonossoff, G. P. 1995. Pathogen-derived resistance to plant virus. Annu. Rev. Phytopathol. 33:323-343.

22. Mekako, H. U., and Nakasone, H. Y. 1975. Interspecific hybridization among six Carica species. J. Am. Soc. Hortic. Sci. 100:294-296.

23. Moreno, M., Bernal, J. J., Jimenez, I., and Rodriguze-Cerezo, E. 1998.
Resistance in plants transformed with the $\mathrm{P} 1$ or $\mathrm{P} 3$ gene of tobacco vein mottling potyvirus. J. Gen. Virol. 79:2819-2827.

24. Mueller, E., Gilbert, J., Davenport, G., Brigneti, G., and Baulcome, D. C. 1995. Homology-dependent resistance: transgenic virus resistance in plants related to homology-dependent gene silencing. Plant J. 7:10011013.

25. Murashige, T., and Skoog, F. 1962. A revised medium for rapid growth and bioassays with tobacco tissue cultures. Physiol. Plant 15:473-497.

26. Niebel, F. d. C., Frendo, P., van Montagu, M., and Cornelissen, M. 1995. Post-transcriptional cosuppression of $\beta$-1,3-glucanase genes dose not affect accumulation of transgene nuclear mRNA. Plant Cell 7:346358.

27. Pang, S. Z., Jan, F. J., Carney, K., Stout, J., Tricoli, D. M., Quemada, H. D., and Gonsalves, D. 1996. Post-transcriptional transgene silencing and consequent tospovirus resistance in transgenic lettuce are affected by transgene dosage and plant development. Plant J. 9:899-909.

28. Pang, S. Z., and Sanford, J. C. 1988. Agrobacterium-mediated gene transfer in papaya. J. Am. Soc. Hortic. Sci. 113:287-291.

29. Powell-Abel, P., Nelson, R. S., De, B., Hoffman, N., Rogers, S. G., Fraley, R. T., and Beachy R. N. 1986. Delay of disease development in transgenic plants that express the tobacco mosaic virus coat protein gene. Science 232:738-743.

30. Purcifull, D. E., Edwardson, J. R., Hiebert, E., and Gonsalves, D. 1984. Papaya ringspot virus. CMI (Commonw. Mycol. Inst.) Descr. Plant Viruses No. 84.

31. Quemada, H., L'Hostis, B., Gonsalves, D., Reardon, I. M., Heinrikson, R., Hiebert, L., Sieu, L. C., and Silghtom, J. L. 1990. The nucleotide sequences of the $3^{\prime}$-terminal regions of papaya ringspot virus strains $\mathrm{W}$ and P. J. Gen. Virol. 71:203-210.

32. Saiki, R. K., Gelfand, D. H., Stoffel, S., Scharf, S. J., Higuchi, R., Horn, G. T., Mullis, K. B., and Erlich, H. A. 1988. Primer-directed amplification of DNA with a thermostable DNA polymerase. Science 239:487491.

33. Sambrook, J., and Russell, D. W. 2001. Molecular Cloning: A Laboratory Manual. 3rd ed. Cold Spring Harbor Laboratory, Cold Spring Harbor, NY.

34. Sanford, J. C., and Johnson, S. A. 1985. The concept of parasite-derived resistance. Deriving resistance genes from the parasites own genome. J. Theor. Biol. 113:395-405.

35. Sanger, F., Nicklen, S., and Coulson, A. R. 1977. DNA sequencing with chain-termination inhibitor. Proc. Natl. Acad. Sci. USA 83:571-579.

36. Sijen, T., Wellink, J., Hiriart, J. B., and van Kammen, A. 1996. RNAmediated virus resistance: Role of repeated transgenes and delineation of targeted regions. Plant Cell 8:2277-2294.

37. Sinisterra, X. H., Polston, J. E., Abouzid, A. M., and Hiebert, E. 1999. Tobacco plants transformed with modified coat protein of tomato mottle begomovirus show resistance to virus infection. Phytopathology 89:701706.

38. Smith, H. A., Swaney, S. L., Park, T. D., Wernsman, E. A., and Dougherty, W. G. 1994. Transgenic plant virus resistance mediated by untranslatable sense RNAs: Expression, regulation, and fate of nonessential RNAs. Plant Cell 6:1441-1453.

39. Tennant, P. F., Gonsalves, C., Ling, K. S., Fitch, M., Manshardt, R., Slightom, J. L., and Gonsalves, D. 1994. Differential protection against papaya ringspot virus isolates in coat protein gene transgenic papaya and classically cross-protected papaya. Phytopathology 84:13591366.

40. Vaucheret, H., Beclin, C., Elmayan, T., Feuerbach, F., Godon, C., Morel, J. B., Mourrain, P. Palauqui, J. C., and Vernhettes, S. 1998. Transgeneinduced gene silencing in plants. Plant J. 16:651-659.

41. Wang, C. H., Bau, H. J., and Yeh, S. D. 1994. Comparison of the nuclear inclusion B protein and coat protein genes of five papaya ringspot virus strains distinct in geographic origin and pathogenicity. Phytopathology 84:1205-1210.

42. Wang, C. H., and Yeh, S. D. 1992. Nucleotide sequence comparison of the 3 '-terminal regions of severe, mild and non-papaya infecting strains of papaya ringspot virus. Arch. Virol. 127:345-354.

43. Wang, C. H., and Yeh, S. D. 1997. Divergence and conservation of the genomic RNAs of Taiwan and Hawaii strains of papaya ringspot potyvirus. Arch. Virol. 142:271-285.

44. Wang, H. L., Wang, C. C., Chiu, R. J., and Sun, M. H. 1978. Preliminary study on papaya ringspot virus in Taiwan. Plant Prot. Bull. 20:133140.

45. Wang, H. L., Yeh, S. D., Chiu, R. J., and Gonsalves, D. 1987. Effectiveness of cross-protection by mild mutants of papaya ringspot virus for control of ringspot disease of papaya in Taiwan. Plant Dis. 71:491-497.

46. Yang, J. S., and Ye, C. A. 1992. Plant regeneration from petioles of in vitro regenerated papaya (Carica papaya L.) shoots. Bot. Bull. Acad. 
Sin. 33:375-381

47. Yeh, S. D., and Gonsalves, D. 1984. Evaluation of induced mutants of papaya ringspot virus for control by cross protection. Phytopathology 74:1086-1091.

48. Yeh, S. D., and Gonsalves, D. 1994. Practices and perspective of control of papaya ringspot virus by cross protection. Adv. Dis. Vector Res. 10:237-257.

49. Yeh, S. D., and Gonsalves, D., and Provvidenti, R. 1984. Comparative studies on host range and serology of papaya ringspot virus and watermelon mosaic virus 1. Phytopathology 74:1081-1085.

50. Yeh, S. D., Gonsalves, D., Wang, H. L., Namba, R., and Chiu, R. J. 1988. Control of papaya ringspot virus by cross protection. Plant Dis. 72:375-380.

51. Yeh, S. D., Jan, F. J., Chiang, C. H., Doong, T. J., Chung, P. H., and Bau, H. J. 1992. Complete nucleotide sequence and genetic organization of papaya ringspot virus RNA. J. Gen. Virol. 73:2531-2541. 